\title{
Bede's Theology of Circumcision, its Sources and Significance
}

Abstract: The Anglo-Saxon theologian Bede (d.735) declared in no uncertain terms that what baptism was for Christians under the new dispensation, circumcision had been for Jews under the old - a genuine sacramental means to remove original sin. In arguing this he drew upon previous comments by Augustine and Gregory the Great, but went beyond them in the clarity and extent of his argument. While Augustine had been the first Latin Father to suggest that circumcision had removed original sin for the children of Israel in the context of his writings against Pelagianism, Bede developed his ideas in ways which seem to reflect the ecclesiastical disputes of early medieval Britain more than of late antique North Africa. The focus upon correct cultic action, rather than mere creedal orthodoxy, in the Easter Controversy of the seventh century may explain why Bede downplayed the importance of faith alone in Augustine's writings and chose to highlight the sacramental power of circumcision and sacrifice before Christ's coming. Bede's use of the patristic writings on circumcision's sacramental status would prove influential in determining how later theologians read the Fathers.

'It is commonly admitted by all that original sin was remitted in circumcision." ${ }^{1}$ So wrote Thomas Aquinas when grappling with the question as to whether circumcision had bestowed grace during the Old Testament. Certainly the Venerable Bede (d.735), the early AngloSaxon theologian, would have been very much in agreement with such a statement.

His homily on Christ's circumcision put a great deal of emphasis upon the fact that circumcision in the past, like baptism in the present, had been provided as a grace 'for taking away the first transgression'. ${ }^{2}$ The (almost) perfect equality of the two sacraments, the old and the new, was something which he spelled out with striking clarity:

circumcision offered the same help of a health-giving treatment against the wound of original sin that now, in the time of revealed grace, baptism is wont to do, except that they [who were under the law] could not yet enter the gate of the heavenly kingdom,

\footnotetext{
${ }^{1}$ Thomas Aquinas, Summa Theologiae, 3, q. 70, a. 4, co., ed. Roberto Busa, Opera Omnia (7 vols., Stuttgart: Frommann-Holzboog, 1980), ii, p. 884: 'ab omnibus communiter ponitur quod in circumcisione originale peccatum remittebatur'; translation from James J. Cunningham, St Thomas Aquinas Summa Theologiae: Volume 57. Baptism and Confirmation (London: Eyre \& Spottiswoode 1975), p. 167.

${ }^{2}$ Bede, Homeliae evangelii, 1.11, ed. David Hurst (CCSL 122; Turnhout: Brepols, 1955), pp. 74-5: 'Vtraque ergo purificatio et circumcisionis uidelicet in lege et in euangelio baptismatis tollendae praeuaricationis primae gratia posita est'; translation from Lawrence T. Martin and David Hurst, Bede the Venerable: Homilies on the Gospels, vol. 1 (Kalamazoo, MI: Cistercian Publications, 1991), p. 105.
} 
until by his coming he who gave the law would give his blessing ... and so, consoled in the bosom of Abraham by a blessed rest after death, they awaited with blissful hope their entry into heavenly peace. ${ }^{3}$

This homily cannot be dated but Bede expressed identical ideas about the cleansing qualities of ancient circumcision in the final book of his commentary on Genesis which he worked upon during the early years of the 720 s. There he wrote that

what baptism in the faith of Christ now does, was at that time done by circumcision on the eighth day... However, the entrance of the heavenly kingdom did not lie open to the circumcised until, rising again from death, the Lord unbolted the gate of that kingdom to all of the elect by ascending to heaven. ${ }^{4}$

By this date at the latest, the Anglo-Saxon had firm ideas about how similar Old Testament circumcision had been to New Testament baptism; the old sacrament was clearly not as effective as the modern one but Bede's language emphasised equivalence rather than difference.

We can actually push Bede's belief in circumcision's power to remit original sin back earlier than the 720 s to sometime between 710 and 715 when he was writing his commentary on Luke's Gospel. There, commenting upon Christ's circumcision, the exegete suggested that the meaning of the sign first received by Abraham was multivalent: circumcision was a seal of Abraham's justice of faith and a prophecy of Christ's cleansing action in the future, but 'chiefly' it was 'a gift of remission which loosened one from the sin of Adam's transgression at that time'. 5 This probably constituted the earliest comment Bede made about the grace-

\footnotetext{
${ }^{3}$ Ibid., p. 74: 'idem salutiferae curationis auxilium circumcisio in lege contra originalis peccati uulnus agebat quod nunc baptisma agere reuelatae gratiae tempore consueuit excepto quod regni caelestis ianuam necdum intrare poterant donec adueniens benedictionem daret qui legem dedit ... tantum in sinu Abrahae post mortem beata requie consolati supernae pacis ingressum spe felici expectabant'; translation from Martin and Hurst, Homilies on the Gospels, pp. 104-5.

${ }^{4}$ Bede, Libri quatuor in principium Genesis usque ad nativitatem Isaac et eiectionem Ismahelis adnotationum, 4, ed. C.W. Jones (CCSL 118A; Turnhout: Brepols, 1967), p. 206: 'Quod enim nunc facit baptismum in fide Christi, hoc fecit ex illo tempore circumcisio in die octaua ... excepto quod circumcisis necdum regni celestis parebat ingressus priusquam resurgens a morte Dominus omnibus electis eiusdem regni ianuam ad caelos ascendendo reseraret'; translation from Calvin B. Kendall, Bede: On Genesis (Liverpool: Liverpool University Press, 2008), p. 284.

${ }^{5}$ Bede, In Lucae evangelium expositio [hereafter: In Lucam], 1, ed. David Hurst (CCSL 120; Turnhout: Brepols, 1960), p. 56: 'Erat autem circumcisionis typus ac figura multiformis. Nam et signaculum ... iustitiae fidei Abrahae et semini eius et indicium castigandi eos qui ad hoc semen hancque fidem perinerent ab omni inquinamento carnis et spiritus et prophetiam nascituri de hoc semine saluatoris qui nos et in praesenti per baptismum ab omni mortiferae actionis pollutione mundaret et in in futuro per resurrectionem ab uniuersa mortis ipsius corruptione in perpetuum liberaret et praecipue donum remissionis quod solueret a peccato praeuaricationis Adae per hanc id temporis ministrari eidem gratiae legisque latori complacuit'; my translation.
} 
giving powers of Old Testament circumcision and probably served as the source for his homily on the same text.

In both the homily and On Luke, Bede equated Old Testament circumcision and New Testament baptism by suggesting that John 3:5 and Genesis 17:14 were effectively the same divine command, allowing for the different sacraments at different times:

For he who now says "unless a man be born again of water and the Holy Spirit, he cannot enter the kingdom of God", then said "The male, whose flesh of his foreskin shall not be circumcised, that soul shall be destroyed out of his people: because he hath broken my covenant". 6

On Luke does not mention the single difference between the circumcision of the past and the baptism of the present - namely, that the old sacrament did not provide immediate access to heaven upon death because this had to await Christ opening up heaven to humans at his passion; that Bede's homily shares this point with On Genesis suggests that it postdates the Lucan commentary. Thus, only over time did Bede come to consider this key difference between the ancient sacrament and the new one, his initial focus having been on the basic equivalence of circumcision in the past and baptism in the present.

\section{Emphasising the essential parallelism of circumcision with baptism so forcefully, Bede felt} the need to explain how the latter's limitation to the family of Abraham did not limit grace to that family. In both On Luke and the homily on Christ's circumcision, he acknowledged that God had provided means for the faithful who lived before Abraham, or who after Abraham came from the gentiles (such as Job did), to cleanse themselves of original sin. Bede believed that such people would have offered sacrifices to God which had a similar effect to the circumcision of the male - or at least they would have been cleansed by faith alone. ${ }^{7}$ Similarly, in On Genesis, after reflecting on how circumcision had only been given to the people of Abraham, Bede stated that 'in other peoples there could still have been some ... purified from the stain of the first transgression either by offerings of sacrificial victims or at

\footnotetext{
${ }^{6}$ Ibid.: 'Qui enim nunc dicit, Nisi quis renatus fuerit ex aqua et spiritu sancto, non potext introire in regnum Dei, ipse tunc dicebat, Masculus cuius praeputii caro circumcisa non fuerit peribit anima illa de populo suo quia pactum meum irritum fecit'; my translation (drawing upon Douay Rheims for the biblical verses). Also Bede, Homeliae, i.11, ed. Hurst, p. 74: 'Qui enim nunc per euangelium suum terribiliter ac salubriter clamat, Nisi quis renatus ..., ipse dudum per legem suam clamabat, Masculus cuius ...'.

${ }^{7}$ Bede, In Lucam, 1, ed. Hurst, pp. 56-7; Bede, Homeliae, 1.11, ed. Hurst, p. 75.
} 
any rate by the profession alone of the true faith'. ${ }^{8}$ Interestingly, Bede never seems to have been troubled by the question as to how women of the tribe of Abraham were freed of original sin, when the circumcision of the foreskin was necessarily denied them. ${ }^{9}$

The Northumbrian clearly, therefore, had a firm view of the sacramental power of ancient Jewish circumcision and expressed its essential (if incomplete) equivalence with baptism on a number of occasions throughout his mature work. But if Aquinas' statement that '[i]t is commonly admitted by all' that circumcision once had the power to remove original sin is correct then why is anything Bede had to say about the subject of interest? In truth, Aquinas' sweeping statement seems a little simplistic and in fact potentially masked a subtle progression in patristic thought on this question: a progression in which Bede had an important role to play.

Commentators, medieval and modern, give Augustine pride of place in the development of this view of Old Testament circumcision, with his anti-Pelagian text On Marriage and Concupiscence usually seen as the key work here. ${ }^{10}$ Aquinas, Gratian, Peter Lombard and Peter Abelard all quoted from the second book of this work to provide authoritative patristic backing for their belief that circumcision removed original sin, but their quotations were often subtly different from each other's and indeed from the text of Augustine (at least as established in the modern critical edition) in ways which suggest the weight of tradition distorting the subsequent reception of Augustine's writing. Both Aquinas and Gratian quoted the bishop of Hippo as having said that: 'From the time that circumcision was instituted among the people of God ... it availed children for the sanctification of cleansing them of the original and old sin. ${ }^{11}$ Peter Lombard was even clearer, having Augustine declare that circumcision 'availed for the cleansing ... of the original and old $\sin { }^{12}$

\footnotetext{
${ }^{8}$ Bede, In principium Genesis, 4, ed. Jones, p. 234: 'in ceteris uero gentibus potuisse adhuc esse nonnullos ... uel hostiarum uidelicet oblationibus uel certe sola uerae fidei professione a primae praeuaricationis labe purgatos'; translation from Kendall, Bede: On Genesis, pp. 312-3.

${ }^{9}$ Heiric of Auxerre in the ninth century may have been the first to address this point in a homily which borrows very heavily from Bede's own homily on Christ's circumcision (a dependence not noted in the critical edition), but also adds a line about Jewish women (Homiliae per circulum anni, I.15, ed. R. Quadri (CCCM 118; Turnhout: Brepols, 1992), p. 128): 'Sed et mulieribus sublegalibus idem est sentiendum, quarum sexui licet circumcisio mandata non fuerit, tamen, ut dictum est, oblationum frequentia fideique puritate se ab originali peccato soluebant.' See also Shaye J.D. Cohen, Why Aren't Jewish Women Circumcised? Gender and Covenant in Judaism (Berkeley, CA: University of California Press, 2005), pp. 87-90.

${ }^{10}$ For modern citation see, for example, Leo Steinberg, The Sexuality of Christ in Renaissance Art and Modern Oblivion, (2 $2^{\text {nd }}$ edn.; Chicago, IL: University of Chicago Press, 1996), pp. 50-51.

${ }^{11}$ Aquinas, Summa theologiae, 3, q. 70, a. 4, s.c., ed. Busa, p. 884: 'quod augustinus dicit, ad valerium contra iulianum, ex quo instituta est circumcisio in populo dei ... ad sanctificationem purgationis valebat parvulis originalis veterisque peccati'; translation adapted from Cunningham, Summa Theologiae, p. 167; Gratian, Decretum, 3.iv.6, ed. Emil Freiberg, in Corpus Iuris Canonici, 2 vols. (Leipzig: Tauchnitz, 1879), i, p. 1363:
} 
Only Abelard seems to have used a text of Augustine which matches that of the current critical edition (in the apparatus criticus of which, interestingly, the alternative readings of Aquinas, Gratian and Peter Lombard do not appear): he quotes the great Father as having said that circumcision availed 'to signify the cleansing' of original sin. Ad significationem appears to be what Augustine wrote, not ad sanctificationem as Aquinas thought. ${ }^{13}$ A slight difference, but clearly an important one; it would appear that Augustine's own words did not explicitly state that circumcision cleansed anyone of original sin - simply that circumcision signified that cleansing. Possibly he may have nonetheless intended here to refer to the cleansing of the Old Testament elect, with circumcision being the external sign meant to indicate membership of the community of the saved (but not necessarily having any power to save in itself ${ }^{14}$ ) - but a typological link between circumcision and baptism may just as easily be referred to here. ${ }^{15}$ The cleansing signified by circumcision could be that which all Christians experience in baptism.

The key point is that the mechanics of Old Testament sacraments held little interest for Augustine. He wished to emphasise that when Genesis 17:14 stated that the eight-day old male had to be circumcised lest he be punished for breaking God's covenant the covenant in question cannot have been that of circumcision since the child was too young to be responsible for this and, hence, could not have broken the command by failing to get himself circumcised. It must therefore, Augustine argued, be the covenant which the boy had broken in Adam to which Genesis referred. ${ }^{16}$ The bishop here used the Old Testament in a polemical context to prove the existence of original sin; circumcision on the eighth day signified, in $O n$ Marriage and Concupiscence, Christ's role in cleansing the soul of original sin through his

\footnotetext{
'Item Augustinus Valerium contra Iulianum. Ex quo instituta est circumcisio in populo Dei ... ad sanctificationem purgationis ualebat paruulis originalis ueterisque peccati'.

${ }^{12}$ Peter Lombard, Sententiae, 4, d. 1, c. 17, 2 vols. (Spicilegium Bonaventurianum, 4-5; Grottaferrata: Collegii S. Bonaventurae, 1971-81), ii, p. 236: 'Unde Augustinus: "Ex quo instituta est circumcisio in populo Dei ... ad purgationem valebat, magnis et parvulis, originalis veterisque peccati'; my translation.

${ }^{13}$ Peter Abelard, Sic et Non, 109.1, ed. Blanche Boyer and Richard McKeon, Peter Abailard Sic et Non: A Critical Edition (Chicago, IL : University of Chicago Press, 1976-77), p. 355 : 'Ex quo enim instituta et circumcisio in populo Dei ... ad significationem purgationis valebat et parvulis veteris originalisque peccati'; Augustine, De nuptiis et concupiscentia, 2.xi.24, ed. C.F. Urba and J. Zycha (CSEL 42; Vienna: Österreichische Akademie der Wissenschaften, 1902), pp. 276-7: 'ex quo enim instituta est circumcisio in populo dei ... ad significationem purgationis ualebat et paruulis originalis ueterisque peccati'.

${ }^{14}$ This is the interpretation of Nina E. Livesey, Circumcision as a Malleable Symbol (Tübingen: Mohr, 2010), p. 132.

${ }^{15}$ E.g. Augustine, De nuptiis, 2.xi.24, ed. Urba and Zycha, p. 276: 'hoc in illo significabatur expiari circumcisione octaui diei, hoc est sacramento mediatoris in carne uenturi'.

${ }^{16}$ Ibid.: 'dicat iste, si potest, quomodo puer ille testamentum dei dissipauit octo dierum, quantum ad ipsum proprie adtinet, innocens infans, et tamen nullo modo deus uel sancta scriptura id mendaciter diceret. tunc ergo dissipauit testamentum dei, non hoc de imperata circumcisione, sed illud de ligni prohibitione, quando per unum hominem peccatum intrauit in mundum'.
} 
work as redeemer. Augustine also made use of this interpretation of Genesis 17:14 in The City of God, which contains another significant discussion of circumcision in an anti-Pelagian context. $^{17}$

In neither case was Augustine's concern really with what circumcision did for ancient Jews living under the Law; his focus remained almost on entirely on what circumcision signified for Christians living in the age of grace. This, of course, does not necessarily mean that he did not think circumcision remitted original sin. On Marriage and Concupiscence does not say this explicitly (even if later theologians thought it did): there Augustine typically wished to emphasise the Pauline point that Abraham was justified by faith alone and not by the act of circumcision. ${ }^{18}$ Elsewhere in his anti-Pelagian corpus, however, writing against Julian of Eclanum, the bishop of Hippo spoke rather more clearly. When explaining how even parents cleansed of original sin by grace can pass that sin onto their children in the seed, Augustine pointed to how the sons of circumcised fathers still had foreskins which needed to be removed in turn: this delivered the clear message that original sin 'would never have come to the infants from whom it had to be removed by circumcision, unless it had been in the seed'. ${ }^{19}$ The foreskin symbolized the biological passing of original sin down through the generations, reminding the Old Testament elect of the need to cleanse the latter by removing the former.

That was all Augustine seems to have said about the point here and his comments bear little similarity to those of Bede, who, in any case, may not have known Against Julian. ${ }^{20}$ Rather more like the Anglo-Saxon's discussion was Augustine's comment in one of his letters that 'circumcision served instead of baptism for the saints of old'; as Bede had been, Augustine was left wondering how things worked for the faithful before receipt of the commandment to circumcise male children and concluded that they were saved by their faith in Christ yet to

\footnotetext{
${ }^{17}$ Augustine, De civitate Dei, 16.27, ed. Bernard Dombart and Alphonse Kalb (CCSL 47-8; Turnhout: Brepols, 1955), pp. 531-2.

${ }^{18}$ Augustine, De nuptiis, 2.xi.24, p. 277: 'nam cum adhuc esset in praeputio, ex fide iustificatus est ipse Abraham'. Livesy, Malleable Symbol, p. 132; Cohen, Jewish Women, p. 85.

${ }^{19}$ Augustine, Contra Julianum pelagianum, 6.vii.19 (PL 44, col. 834): 'ipsa pars corporis ob hoc jussa est amputari, ut hoc vitium purgaretur. Quod nisi esset in semine, ad parvulos, quibus circumcisione illa corporis auferendum est, nullatenus perveniret: neque si minime pervenisset, indigeret ullatenus hac corporis circumcisione semoveri'; translation from Matthew Schumacher, Saint Augustine: Against Julian (Fathers of the Church 35; Washington, DC: Catholic University of America Press, 1957), p. 328 (my emphasis).

${ }^{20}$ Nicolas De Maeyer, 'Bede as a compiler: the Collectio ex opusculis sancti Augustini in epistulas Pauli apostolic and the Venerable Bede's presentation of Augustine's Pauline exegesis', paper delivered at the XVII ${ }^{\text {th }}$ International Conference on Patristic Studies, Oxford, $10^{\text {th }}-14^{\text {th }}$ August 2015, argued that Bede only knew this work via Eugippius' Excerpta.
} 
come, just as now Christians are saved by their faith in Christ having come. ${ }^{21}$ These comments in Against Julian and Letter 187, neither of which we can be sure Bede read, are as clear as Augustine got concerning the grace-bestowing effects of circumcision. ${ }^{22} \mathrm{He}$ certainly defended Old Testament Jewish cult elsewhere, such as in Against Faustus (a work very influential on Bede) where he made it clear that Israel had genuinely pleased the Almighty through the carnal ceremonies of the Law, animal sacrifice and circumcision amongst them; but the focus there remained upon circumcision's typological importance, not its sacramental effect. $^{23}$

So while the bishop of Hippo may have established the idea that circumcision cleansed original sin, one cannot say that he provided the direct source for this idea, expressed with much more explicit clarity, in Bede's writings. While Bede was familiar with, and cited, Augustine's argument that Genesis 17:14 proved the existence of original sin, in general his approach to Old Testament circumcision differed notably from that of the earlier Father. ${ }^{24}$ Augustine never stated that circumcision did once what baptism does now, except allow immediate access to heaven - as Bede did. Augustine never declared that the divine commands of Genesis 17:14 and John 3:5 were effectively equivalent - as Bede did. Both theologians were exercised by the question as to how those to whom circumcision was denied could have been justified before the coming of Christ, but Bede's solution to this problem was much more detailed than Augustine's sole focus on faith.

That is in part because of Bede's reading of Gregory the Great, whose massive commentary on Job gave the pope occasion to reflect upon the salvation of the gentiles during the Old Testament. In the Moralia Gregory stated:

\footnotetext{
${ }^{21}$ Augustine, Epistulae, 187.xi.34, ed. A. Goldbacher, (CSEL 57; Vienna: Österreichische Akademie der Wissenschaften, 1911), p. 112: 'quod si circumcisio antiquis sanctis pro baptismo fuisse creditur, quid respondebitur de his, qui, antequam hoc praceptum esset, deo placuerunt non tamen sine fide, quia sine fide, ut scriptum est ad Hebraeos, inpossibile est placere? ... sicut autem illi, quando idem sacramentum occultum erat, credebant Christi incarnationem futuram, sic et nos credimus factam'; translation adapted from Wilfrid Parsons, Saint Augustine: Letters Volume IV (165-203) (Fathers of the Church, 30; Washington, DC: Catholic University of America Press, 1955), p. 249.

${ }^{22}$ The only section of Letter 187 which we can be sure Bede read is that in Eugippius' Excerpta: Paul-Irénée Fransen, 'Description de la collection de Bède le Vénérable sur l'Apôtre', Revue Bénédictine 71 (1961), 22-70, p. 50; Eugippius, Excerpta ex operibus Sancti Augustini, 113.338, ed. Pius Knoell (CSEL 9; Vienna: Österreichische Akademie der Wissenschaften, 1885), pp. 1004-7.

${ }^{23}$ E.g. Augustine, Contra Faustum, 19.9, ed. Joseph Zycha (CSEL 25; Vienna: Österreichische Akademie der Wissenschaften, 1891), p. 507; for Against Faustus' influence on Bede: Conor O'Brien, Bede's Temple: An Image and its Interpretation (Oxford, 2015), p. 53.

${ }^{24}$ Bede, In principium Genesis, 4, ed. Jones, p. 206; Augustine, De civitate Dei, 16.27, ed. Dombart and Kalb, pp. 531-2.
} 
Whoever is not absolved by the water of regeneration, is held bound by the guilt of the original bond. Because that which the water of baptism achieves amongst us, amongst the ancients either faith alone for children, or the power of sacrifice for elders, or, for those who had come from Abraham's line, the rite of circumcision achieved. ${ }^{25}$

The three salvific options which Bede would later suggest were open to the pre-incarnation elect of circumcision, sacrifice and faith were here linked apparently for the first time. While never directly quoting the above passage, the Northumbrian seemed to acknowledge his dependence upon Gregory in On Genesis, where, having spoken of those 'purified from the stain of the first transgression either by offerings of sacrificial victims or at any rate by the profession alone of the true faith', he went on to state that '[t]he blessed Pope Gregory concurs with this opinion, when he says that we must certainly not believe that so slight a number of men in those times had attained to eternal life as the law-giver Moses seems to apprehend'. ${ }^{26}$

This specific reference to Moses in Gregory's work has not been identified and Bede here may well have extrapolated from what he knew Gregory had said, or perhaps misremembered the statement in the Moralia, a work with which he was certainly very familiar. Nevertheless, the statement suggests that Bede was aware that he had derived the idea of the three means of cleansing original sin from the pope. Augustine may have laid the foundations for a tradition of understanding Old Testament circumcision as having a sacramental effect similar to that of baptism, but Bede appears to have accessed this tradition via its later Gregorian development. But Bede's three discussions of circumcision's cleansing effects all go beyond Gregory's single comment. In other words, the tradition continued to develop throughout the early Middle Ages.

Most significantly, I have found no sign of any Latin author prior to the eighth century linking Genesis 17:14 and John 3:5 as Bede does. This particular appeal to scripture for the close similarity, indeed the nigh identity, of circumcision and baptism appears to have only

\footnotetext{
${ }^{25}$ Gregory, Moralia in Iob, 4.pref.3, ed. Mark Adriaan (CCSL 143; Turnhout: Brepols, 1979), p. 160: 'Quisquis enim regenerationis unda non soluitur, reatu primi uinculi ligatus tenetur. Quod uero apud nos ualet aqua baptismatis, hoc egit apud ueteres uel pro paruulis sola fides, uel pro maioribus uirtus sacrificii, uel pro his qui ex Abrahae stirpe prodierant, mysterium circumcisionis'; my translation.

${ }^{26}$ Bede, In principium Genesis, 4, ed. Jones, p. 234: 'uel hostiarum uidelicet oblationibus uel certe sola uerae fidei professione a primae praeuaricationis labe purgatos ... Cum sententiae congruit beatus papa Gregorius, dicens nequaquam esse credendum tam breuem hominum summam illis temporibus ad uitam peruenisse perpetuam quam legifer Moyses ... uidetur comprehendere'; translation from Kendall, Bede: On Genesis, p. 313
} 
entered the tradition with Bede's own writings. Once Bede had introduced this trope subsequent continental writers picked up on it: for example, Haimo of Auxerre's homily on the Lord's circumcision derives this point from Bede's homily on the same subject with close verbal parallels evident between the two works. ${ }^{27}$ The fact that Bede seems to have first developed this point is not unimportant, since it provides more than an additional illustration of an already long-established teaching. It expresses the essential continuity of circumcision and baptism which Bede sought to make clear and in that respect stands somewhat removed from the common Christian belief that circumcision provided the type of which baptism was the fulfilment. ${ }^{28}$

Bede, in other words, did not simply express ideas which had originally been Augustine's rather more bluntly; he, in fact, said something subtly different. The different circumstances in which both exegetes thought and wrote led them to emphasise different things and to construct their arguments in very different ways. The Donatist dispute, with its debates concerning the sacramental purity of the visible and institutional Church, understandably provided the circumstances for Augustine to defend the material practices of Old Testament Jewish cult, including bodily circumcision and material sacrifices. ${ }^{29}$ But it was not in those circumstances, not in Against Faustus and similar works, that he seems to have developed the idea that circumcision gave grace and removed original sin, rather it was years later when writing against Pelagianism.

This explains why Augustine's main statements on ancient circumcision in On Marriage and Concupiscence, The City of God and Against Julian are directed towards providing scriptural backing for the doctrine of original sin. But it also explains Augustine's focus upon faith as the key to salvation of the elect of the Old Testament. Suspicious of the Pelagian emphasis upon the individual's ability to work their own salvation through good actions, without apparently needing the grace of the crucified Christ, the bishop of Hippo chose to highlight that it was faith in Christ which saved people from original sin before the incarnation,

\footnotetext{
${ }^{27}$ Haimo, Homiliae, 14 (PL 118, col. 91): 'Nec putandum est, parvam utilitatem suo tempore habuisse circumcisionem: sed sciendum quia tantum valebat tunc circumcisio contra originale peccatum, quantum nunc valet aqua baptismatis, excepto quod ille nondum venerat, qui peccata solvere posset, vel qui januam regni coelestis reseraret. Quoniam qui nunc per Evangelium dicit: Nisi quis renatus fuerit ex aqua et Spiritu sancto, non potest intrare in regnum Dei, ipse tunc per legem clamabat: Masculus cujus caro praeputii circumcisa non fuerit, peribit anima illa de populo suo, quia pactum meum irritum fecit'. Also Heiric, Homiliae, I.15, ed. Quadri, p. 128.

${ }^{28}$ On the common association of circumcision and baptism in the Fathers: Everett Ferguson, 'Spiritual Circumcision in Early Christianity', Scottish Journal of Theology 41 (1988), pp. 485-97.

${ }^{29}$ Paula Fredriksen, Augustine and the Jews: A Christian Defense of Jews and Judaism (New York: Doubleday, 2008), esp. ch. 9-10.
} 
including Abraham himself, of course. Circumcision signified the cleansing power of faith, something which Abraham already possessed through grace, rather than worked the cleansing of sin through its own performance; for that reason Augustine could claim that it was not the ancient covenant, nor the Jewish Law, which saved, but 'the grace of God through Jesus Christ our Lord' ${ }^{30}$ Overt attention to the sacramental role of circumcision and the specific way in which it functioned like baptism did not feature in Augustine's agenda, which was increasingly focused upon battling the scourge of Pelagianism.

The focus upon faith is rather less noticeable in Bede's writings - not least because the Northumbrian suggested, borrowing from Gregory, that the uncircumcised faithful cleansed themselves of original sin through material sacrifices. Whereas for Augustine faith was the overarching answer to the problem of how the uncircumcised could be justified, for Bede it very much played second fiddle to sacrifice, the answer to which he first turned. Bede declared that those faithful from outside Abraham's family could have been cleansed by sacrifices 'or certainly by faith alone': we could possibly even translate the Latin, in a rather more dismissive fashion, as 'at least by faith alone', or 'at any rate by faith alone'. ${ }^{31}$ When Bede wanted to know how these people were saved he thought of an action first of all and of faith itself only subsequently. He depended here upon Gregory the Great, but his multiple statements to this effect were clearly not an unthinking repetition of Gregory's single, rather brief, comment.

Other scholars have previously noted Bede's striking interest in the importance of good works and that, in fact, he subtly adapted the Augustinian teachings on grace to restore to human actions some of the effectiveness which Augustine's later anti-Pelagian writings seemed to deny to them. ${ }^{32}$ In the memorable words of M.T.A. Carroll, Bede insisted on the necessity of works alongside faith ' $[w]$ ith the fervor of an anti-Luther crusader'. ${ }^{33}$ To some extent, Bede in the eighth century combined the earlier anti-Donastist Augustine with the later anti-Pelagian Augustine in his teachings on circumcision - though he would never have

\footnotetext{
${ }^{30}$ Augustine, De nuptiis, 2.xi.24, p. 277: ‘... nam cum adhuc esset in praeputio, ex fide iustificatus est ipse Abraham ... eadem tamen fides mediatoris saluos iustos faciebat antiquos, pusillos cum magnis, non uetus testamentum, quod in seruitutem generat, non lex quae non sic est data, quae posset uiuificare, sed gratia dei per Iesum Christum dominum nostrum [Romans 7:25]'.

${ }^{31}$ Bede, In Lucam, 1, ed. Hurst, p. 57: 'seu certe sola fide'; Bede, In principium Genesis, 4, ed. Jones, p. 234: 'uel certe sola uerae fidei professione'; Bede, Homeliae, 1.11, ed. Hurst, p. 75: 'uel certe sola fidei uirtute'. ${ }^{32}$ Aaron J. Kleist, Striving with Grace: Views of Free Will in Anglo-Saxon England (Toronto: University of Toronto Press, 2008), pp. 68-76. This modification of Augustine had begun in Gregory's works: ibid., pp. 4757.

${ }^{33}$ M.T.A. Carroll, The Venerable Bede: His Spiritual Teachings (Washington, DC: The Catholic University of America Press, 1946), p. 217.
} 
seen his work in those terms. Rather, I would argue, Bede here let slip something important about how he thought of the community of the faithful organised in this world and how he saw salvation working in practice. As Augustine had responded to Pelagius and Julian of Eclanum, so too Bede wrote about circumcision in the context of the ecclesiastical disputes of his own day.

Bede's theology of Old Testament circumcision suggests that, even before Christ's incarnation and the consequent establishment of the Church as an institution in the world, the faithful had gathered around the performance of material and visible sacraments. He seems to have thought of ancient Jewish religion and cult as effectively forming a 'Jewish church' which operated in the past on quite similar grounds to how the Christian Church did in the present. ${ }^{34}$ Notice, for instance, the difference between Gregory the Great's statement about the three means of removing original sin before baptism and Bede's later discussions on the same subject. Gregory put circumcision at the end of his list and implicitly contrasted the general 'children' and 'elders' who availed of faith and sacrifices with the defined and specific group ('those that had come from Abraham's line') for whom circumcision worked. ${ }^{35}$ The implication appears to be that only a small and limited number of people ever utilised circumcision as a sacrament. ${ }^{36}$

Bede, however, always put circumcision in the foreground as the Old Testament equivalent of baptism. Certainly, he never forgot that it was limited to the descendants of Abraham and, very self-consciously a gentile himself, he went to some trouble to show that this did not mean the gentiles lived without opportunities to cleanse themselves of original sin. But Bede's approach prioritised, rather than side-lined, the organised community of worshippers devoted to God formed by the Old Testament Jewish nation. ${ }^{37}$ The Northumbrian was very interested in ancient Judaism and was, in many respects, strikingly sympathetic to and positive about the Jews who had worshipped God before Christ's incarnation. He thought of these worshippers as being grouped in an institution called the Synagogue (identified with the

\footnotetext{
${ }^{34}$ Conor O'Brien, 'Bede on the Jewish Church', in Peter D. Clarke and Charlotte Methuen (eds), The Church on its Past (Woodbridge: Boydell \& Brewer, 2013), pp. 63-73, at 64-8; O’Brien, Bede's Temple pp. 149-50.

${ }^{35}$ Gregory, Moralia, 4.pref.3, ed. Adriaan, p. 160 (see above n. 25).

${ }^{36}$ I differ here from Cohen, Jewish Women, p. 85, who accords Gregory a key role in the tradition for misunderstanding Augustine on circumcision (Cohen appears not to have been familiar with those passages where Augustine did imply that the rite of circumcision remitted original sin) and presenting circumcision 'as an alternative to faith'. Certainly, Gregory developed Augustine's ideas but not as dramatically as Cohen implies and not to the same extent as Bede later would.

${ }^{37}$ See Georges Tugène, 'Le thème des deux peuples dans le De Tabernaculo de Bède', in Stéphane Lebecq, Michel Perrin, and Olivier Szerwiniack (eds.), Bède Le Vénérable entre tradition et postéritél The Venerable Bede. Tradition and Posterity (Lille: Université Charles-de-Gaulle, 2005), pp. 73-84.
} 
Jewish nation) which closely paralleled and prepared the way for the gentile Church which would replace it. ${ }^{38}$

As we have seen, Bede carefully pointed out that the faithful before the incarnation were not limited to the Synagogue, but even those gentiles who lived outside that Church-like institution still primarily expressed their devotion to God through cultic acts such as sacrifices. Like Augustine, Bede believed that faith in the one true God brought salvation throughout human history; he, however, wished to make rather clearer than the North African exegete had that this faith had always been best expressed either within formal institutions or through defined cultic acts. This focus on the external forms of worship which provide grace really marks Bede's theology of circumcision and sets it apart from Augustine's and it is a focus which may arise from the nature of Insular Christianity in the early Middle Ages.

The seventh and early eighth centuries saw a, sometimes quite fierce, debate in the Church within Britain, Ireland and Frankia concerning the correct date of celebrating Easter, the correct form of the monastic tonsure and the correct manner of performing baptism. Thinking of this clash as a struggle between a Celtic and a Roman Church (the once traditional approach) has not always proved the most helpful - although the rhetoric of loyalty to the Catholic Church centred in Rome played an important part in the debate. ${ }^{39}$ Clearly the issues at stake were related to sacraments, rituals, and externally obvious signs of one's loyalty to one or other tradition. Conversion from heterodoxy to orthodoxy in these circumstances did not require a creedal statement of right belief - it required the enactment of correct rituals and forms of worship.

The exact liturgical grounds for dispute remain in some cases unclear; in particular we know very little about the exact differences in baptismal custom practiced by the Roman-leaning Church and its rivals. ${ }^{40}$ Much scholarship has suggested that baptism amongst the Britons and Irish did not traditionally include episcopal confirmation and the Old English for baptism, fullwiht, meaning 'complete consecration', might derive from an emphasis upon the liturgical

\footnotetext{
${ }^{38}$ O’Brien, 'Jewish Church', pp. 63, 69; e.g. Bede, Homeliae, 1.18, ed. Hurst, p. 131; Bede, In cantica canticorum, 1, ed. David Hurst (CCSL 119B; Turnhout: Brepols, 1983), pp. 190-91.

${ }^{39}$ For an introduction to the debate: Caitlin Corning, The Celtic and the Roman Traditions: Conflict and Consensus in the early medieval Church (Basingstoke: Palgrave Macmillan, 2006).

${ }^{40}$ See Bede, Historia ecclesiastica gentis Anglorum [hereafter: HE], 2.2, ed. Bertram Colgrave and R.A.B. Mynors, in Bede's Ecclesiastical History of the English People (Oxford: Clarendon Press, 1969), p. 138; Corning, Celtic and Roman, pp. 73-6; Sarah Foot, 'By Water in the Spirit: The Administration of Baptism in early Anglo-Saxon England', in John Blair and Richard Sharpe (eds), Pastoral Care Before the Parish (Leicester: University of Leicester Press, 1992), pp. 171-92, at 172-4.
} 
completeness of baptism with confirmation. ${ }^{41}$ Certainly Bede often chose to link baptism to the subsequent performance of other sacraments, in particular either the laying on of hands by the bishop in confirmation or the eucharist. ${ }^{42}$ In either case liturgical performance was key and it seems likely that, whatever the grounds for dispute about baptism in the Insular world, correct ritual performance played as important a role here as in the Easter Controversy.

Not simply faith, but deeds, mattered in this environment. Bede's own writings reveal this to be the case. He went to some effort to emphasise that the great missionary from Iona to Northumbria, St Aidan, preached exactly the same faith in Christ as those who supported the Roman Easter - Aidan was no heretic. But Bede nonetheless remained clear that Aidan celebrated Easter on the wrong date and that was something of which he could not approve, which Bede indeed detested. ${ }^{43}$ Similarly, Bede's one-time abbot Ceolfrith asserted that one did not need to wear the Petrine tonsure to uphold the Catholic faith - but nonetheless the socalled tonsure of Simon Magus, preferred by the monks of Iona and its dependencies, remained 'abominable and detestable' ${ }^{44}$ Such statements came from the early eighth century, the very end of the controversy, and from a winning side which could now afford to be rather magnanimous to the dead saints of the other party by accepting that they had been doctrinally sound. Nonetheless, in the conviction that external actions had a great importance, that faith was not in itself sufficient to reveal one's membership of the community of the faithful, the late writings probably provide an accurate reflection of ideas formed in the heat of debate during the seventh century.

Witness the interesting comments concerning faith made by Columbanus, a figure on the opposite side of the controversy to Bede and Ceolfrith. Writing in the early seventh century to the bishops of Gaul, with whom he clashed over the dating of Easter, Columbanus highlighted the need to imitate Christ (which by implication the Irishman and his monks did better than secular clerics and bishops who were insufficiently poor and humble). ${ }^{45}$ This

\footnotetext{
${ }^{41}$ Carla Falluomini, 'Fullwiht and the Baptismal Rite in Anglo-Saxon England', Anglia 128 (2010), pp. 391405.

${ }^{42}$ E.g. Bede, In cantica canticorum, 4, ed. Hurst, p. 322; Bede, De templo, 2, ed. David Hurst (CCSL 119A; Turnhout: Brepols, 1969), p. 214. For more on this relationship of baptism to other sacraments see Conor O’Brien, 'Temple, Tabernacle or Something in Between? Architectural Representation in Codex Amiatinus, fols. II ${ }^{\mathrm{v}}-\mathrm{III}^{\mathrm{r}}$, , forthcoming in Leeds Studies in English.

${ }^{43}$ Bede, $H E$, 3.17, ed. and trans. Colgrave and Mynors, pp. 264-6.

${ }^{44}$ Ibid., 5.21, ed. and trans. Colgrave and Mynors, pp. 548-50: 'abominandam detestandamque ... Neque uero me haec ita prosecutum aestimes quasi eos, qui hanc tonsuram habent, condemnandos iudicem, si fide et operibus unitate catholicae fauerint'.

${ }^{45}$ Tommaso Leso, 'Columbanus in Europe: The Evidence of the Epistulae', Early Medieval Europe 21 (2013), pp. 358-89, at 372-4.
} 
imitation focused primarily upon action because 'faith without works is dead in itself, and the Lord replies to fools who rely on faith alone, that "I have not known you", and to those who believe well and keep saying "Lord, Lord", He declared, that they shall not enter into the kingdom of heaven'. ${ }^{46}$ Columbanus may have spoken here in reasonably general terms about the importance of good deeds (understood implicitly as ascetic deeds) but the context of debate and discussion over Easter is interesting. Bede similarly put Matthew 7:23 into the mouth of the champion of the Roman Easter, Wilfrid, at the Synod of Whitby: when the Ionans claimed that they simply followed the Easter and the tonsure of St Columba and other worthy fathers, Wilfrid replied that there would be many on Judgement Day to whom the Lord would say that he never knew them. Better, then, to accept the practices of the universal Church than to cling to those of people 'who', he admitted, 'in their rude simplicity [had] loved God with pious intent'. ${ }^{47}$ That faithful intent could not excuse the incorrect actions.

The Epistle of James' statement that 'faith without works is dead', quoted by Columbanus, was a favourite verse of Bede's but it also appears in a letter of his near-contemporary Aldhelm of Malmesbury which deals with these ecclesiastical disputes. ${ }^{48}$ Writing to the British clerics of Dumnonia, Aldhelm set out the reasons as to why both their tonsure and their Easter calculation were incorrect and why if they wished to enter heaven they should follow the teachings of the key-bearer, Peter. He imagined that 'some wily student of books and clever interpreter of Scriptures' would defend these incorrect practices by asserting his orthodoxy and correctly reciting the creed to prove that he should be numbered 'amongst the community of Catholics, according to the privilege of this faith'. Aldhelm moved swiftly to disabuse his opponents of such a belief, "because "faith without works is dead"". ${ }^{49}$ In other

\footnotetext{
${ }^{46}$ Columbanus, Epistulae, 2.3, ed. and trans. G.S.M. Walker, Sancti Columbani Opera (Dublin: Institute of Advanced Studies, 1957), pp. 14-15: 'Fides sine operibus mortua est in semetipsa [James 2.20], et Dominus fatuis sola fide contentis respondet, Quia non novi vos [Matthew 7:23], et bene credentibus et Domine, Domine [Matthew 7:21], dicentibus promisit, quod non intrabunt in regnum caelorum'.

${ }^{47}$ Bede, $H E$, 3.25, ed. and trans. Colgrave and Mynors, pp. 304-6: 'De patre autem uestro Columba et sequacibus eius, quorum sanctitatem uos imitari ... possem respondere, quia multis in iudicio dicentibus Domino, quod in nomine eius prophetauerint et daemonia eiecerint et uirtutes multas fecerint, responsurus sit Dominus, quia numquam eos nouerit ... illos Dei famulos ac Deo dilectos esse non nego, qui simplicitate rustica sed intentione pia Deum dilexerunt'.

${ }^{48}$ For Bede's use of the phrase: Bede, In cantica canticorum, 5, ed. Hurst, p. 333; Bede, Homeliae, 2.8, ed. Hurst, pp. 235; Bede, De tabernaculo et vasis eius ac vestibus sacerdotum, 3, ed. David Hurst (CCSL 119A; Turnhout: Brepols, 1969), p. 129; Bede, De templo, 1, ed. Hurst, pp. 174, 189. For Bede's formal exegesis of James' comments on faith and works: Bede, In epistolas septem catholicas, ed. David Hurst (CCSL 121; Turnhout: Brepols, 1983), pp. 198-201.

${ }^{49}$ Aldhelm, Epistulae, 4, ed. R. Ehwald (Monumenta Germaniae Historica, Auctores Antiquissimi 15; Berlin: Weidmann, 1919), pp. 480-6, at 485-6: 'Sed fortasse quilibet strofosus librorum lector ac sagax scripturarum disceptator tali se excusationis clipeo defendat et tali se apologiae parma protegat "Ego, inquiens, utriusque instrumenti praecepta sincera fide veneror ac sanctae trinitatis unam essentiam unamque substantiam et trinam personarum subsistentiam corde credulo confiteor... et huius fidei privilegio in catholicorum coetu glomeratus
} 
words, the Britons' creedal orthodoxy, the faith which they asserted, would not be enough to get them into heaven without active participation in the ritual and outward signs of membership of the Catholic Church. Columbanus seems to have made the same point from the opposite side.

If one wished to be recognised as one of the faithful in the early Insular world, by either God or man, one had to display that membership of the elect outwardly using haircuts, rituals, this-worldly actions: these, and not just faith, were the marks of the saved. Bede himself suggested that the incarnation of Christ had made both the good and the wicked reveal themselves in this world through their actions. ${ }^{50}$ His preference for seeing the faithful from before the incarnation as similarly revealed by their bodily features or by their performance of certain rituals of worship seems to be all of a piece with such an attitude, one probably shaped by the importance of rites and practices to the Christians of the Insular world. ${ }^{51}$

Was this apparent downgrading of sola fides and the more explicit focus upon the sacramental effect of Old Testament cultic actions in some way meant to be a riposte to Augustine? Certainly there have been claims that the Church in British and Irish territories in the early Middle Ages existed on a spectrum between Pelagian and Semi-Pelagian with Augustine's theories of grace treated with some suspicion because of the Insular preference for a monastic focus upon the potentially salvific effects of human action. ${ }^{52}$ If a general antiAugustinism was in the Insular air, as it were, might it not have affected how Bede adapted and changed ideas about circumcision which had originally been developed in the context of anti-Pelagian polemic?

One should be rather cautious here about using the language of Pelagianism however, not to mind that of Semi-Pelagianism, something which may only ever have existed in the

sine aliquo infelicitatis obstaculo connumerabor." ... Ait namque Iacobus, materterae domini filius: Tu credis, quia unus est deus et quia per hironiam duodecim tribulus in dispersione constitutis loquebatur, statim subiunxit: Bene facis; et demones credunt et contremescunt, quia fides sine operibus mortua est'; translation from Michael Herren, in Aldhelm: The Prose Works, trans. Michael Lapidge and Michael Herren (Cambridge: D.S. Brewer, 1979), pp. 155-60, at 159-60.

${ }^{50}$ Bede, Homeliae, 1.18, ed Hurst, p. 132.

${ }^{51}$ For more on how the ecclesiastical culture of the Insular world may have shaped Bede's ecclesiology, and in particular its focus upon the Church as a sacramental and visible institution: O'Brien, Bede's Temple, pp. 151-4. ${ }_{52}$ Michael W. Herren and Shirley Ann Brown, Christ in Celtic Christianity: Britain and Ireland from the Fifth to the Tenth Century (Woodbridge: Boydell \& Brewer, 2002). Herren and Brown's thesis has been strongly (and convincingly) contested: Gilbert Márkus, 'Pelagianism and the 'Common Celtic Church', The Innes Review 56 (2005), pp. 165-213; Gerald Bonner, 'The Pelagian Controversy in Britain and Ireland', Peritia 16 (2002), pp. 144-55. 
imaginations of Prosper of Aquitaine and the early modern scholars who invented the term. ${ }^{53}$ To modify Augustine was not the same thing as to embrace Pelagianism; indeed the eventual 'orthodox' teaching on grace, action and free will established in the sixth century fell significantly short of a full-blooded Augustinism as expressed in the bishop of Hippo's late works. ${ }^{54}$ Bede's own anti-Pelagianism and commitment to predestination cannot be doubted, but neither can the fact that he did hold rather different ideas about grace, free will and human action to those of Augustine. ${ }^{55}$ Similarly Columbanus may have been drawn to the writings of Faustus of Rietz (whose attempts to modify extreme Augustinism caused him to be labelled 'Semi-Pelagian'), but he still went to the trouble of condemning outright Pelagianism. ${ }^{56}$

It seems more useful to suggest that in seventh- and eighth-century Britain and Ireland cultic actions really mattered, than that heterodoxy was in the air. What rituals and what outward actions you performed indicated whether you belonged to the community of the righteous or that of the reprobate. The sacramental could be as important as the creedal. Bede did not hold the more extreme viewpoint of those who would not even eat from the vessels contaminated by the touch of those who performed an incorrect Easter; ${ }^{57}$ as he saw the controversy edge towards its conclusion and Roman practices slowly triumph in the eighth century he could probably afford to be somewhat more understanding of difference than some before him had been. But his education in such a climate is unlikely to have left Bede untouched and may very well have played a major role in explaining why he assumed the importance of sacramental actions (circumcision and sacrifice) for removing original sin amongst the Old Testament faithful.

\footnotetext{
${ }^{53}$ Augustine Cassiday, 'Rehabilitating John Cassian: an evaluation of Prosper of Aquitaine's polemic against the "semipelagians", Scottish Journal of Theology 58 (2005), pp. 270-84; Irena Backus and Aza Goudriaan, "'Semi-pelagianism": the origins of the term and its passage into the history of heresy', Journal of Ecclesiastical History 65 (2014), pp. 25-46.

${ }^{54}$ See R.A. Markus, 'The Legacy of Pelagius: Orthodoxy, Heresy and Conciliation', in Rowan Williams (ed.), The Making of Orthodoxy: Essays in Honour of Henry Chadwick (Cambridge: Cambridge University Press, 1989), pp. 214-34.

${ }^{55}$ On Bede's most sustained (though by no means his only) piece of anti-Pelagian polemic: Arthur Holder, 'The Anti-Pelagian Character of Bede's Commentary on the Song of Songs', in Claudio Leonardi and Giovanni Orlandi (eds.), Biblical Studies in the Early Middle Ages (Florence: Sismel, 2005), pp. 91-103, at 92-8. On Bede's difference from Augustine: Kleist, Striving with Grace, pp. 61, 68-76; Rowan Williams, 'Theology and the Paschal Controversy: Bede's Case against the British Church', in Santha Bhattacharji, Rowan Williams and Dominic Mattos (eds.), Prayer and Thought in Monastic Tradition: Essays in Honour of Benedicta Ward SLG (London: Bloomsbury, 2014), pp. 31-44, at 42.

${ }^{56}$ Clare Stancliffe, 'The Thirteen Sermons Attributed to Columbanus', in Michael Lapidge (ed.), Columbanus: Studies on the Latin Writings (Woodbridge: Boydell \& Brewer, 1997), pp. 93-202, at 181-3, 190-91, 197.

${ }^{57}$ Bede, HE, 2.4, ed. and trans. Colgrave and Mynors, p. 146; Aldhelm, Epistulae, 4, ed. Ehwald, p. 484.
} 
It therefore seems likely that while Bede was certainly not the first to declare that circumcision had removed original sin under the old dispensation, how he made that point did constitute a new contribution to the tradition. He probably made this point in a much clearer and more explicit manner than any previous writer: repeating it three times across his writings. He explained of what the sacramental power of circumcision consisted (removing original sin but not opening up access to heaven), backed up the equation of circumcision and baptism with scriptural citation and considered how non-Hebrews might also have dealt with original sin before baptism became available as a sacrament. Augustine's writings on original sin suggested the sacramental power of circumcision and Gregory the Great presented the alternative of sacrifice for the gentiles. Bede drew upon both Fathers to develop a theology of circumcision clearer and more developed than that which either had presented. In this he was neither the unthinking slave to patristic thought which scholarship once judged him, nor the self-consciously original genius modern sensibilities might wish him, to have been. ${ }^{58}$

Bede was working squarely within an existing tradition to which he actively contributed, though not necessarily always intentionally. Nonetheless Bede's writings on circumcision proved to be influential: by the ninth century continental writers were drawing closely upon his pairing of Genesis 17:14 and John 3:5 and explaining, using his words, that circumcision had done everything which baptism did except open the gates of heaven - both points which do not appear in Latin theology before Bede. ${ }^{59}$ The clarity of his arguments, I would suggest, made it easier for later theologians to read Augustine's more ambiguous statements about circumcision as obvious declarations that it cleansed the faithful of old of original sin. That this became the accepted understanding of circumcision probably explains the readings of $O n$ Marriage and Concupiscence which we have explored above.

Certainly when the great synthetic theologians of the twelfth century came to sum up on the question of whether circumcision had destroyed original sin, one can clearly see Bede's mark on their work. Many debates about Old Testament circumcision were still to take place and much subtle thought directed to the problem of the relationship between the sacraments of the old and new dispensations - but the basic starting point of most scholastic writing on the

\footnotetext{
${ }^{58}$ See Scott DeGregorio, 'Introduction: The New Bede', in Scott DeGregorio (ed.), Innovation and Tradition in the Writings of the Venerable Bede (Morgantown, WV: University of West Virginia Press, 2006), pp. 1-10, at 6-9.

${ }^{59}$ See above n. 27.
} 
subject remained the claims made concerning circumcision by Bede. ${ }^{60}$ Peter Lombard and Albert the Great both quoted Bede himself, Abelard drew upon a paraphrase of Bede from a homily of Haimo and when Aquinas declared with confidence that '[i]t is commonly admitted by all that original sin was remitted in circumcision' he did so in part because Bede had assumed the very same point centuries earlier. ${ }^{61}$

\footnotetext{
${ }^{60}$ Richard Schenk, 'Covenant Initiation: Thomas Aquinas and Robert Kilwardby on the Sacrament of Circumcision', in Carlos-Josaphat Pinto de Oliveira (ed.), Ordo Sapientiae et Amoris: Image et message de Saint Thomas d'Aquin à travers les récentes études historiques, herméneutiques et doctrinales (Fribourg: Éditions Universitaires, 1993), pp. 555-93, at 556, 583.

${ }^{61}$ Lombard, Sententiae, 4, d. 1, c. 7, ed. Brady, p. 236; Albertus Magnus, Comentarii in I Sententiarum, 1.7, ed. Auguste Borgnet, Opera Omnia 38 vols. (Paris: Vivès, 1890-99), xxv, p. 21; Abelard, Sic et Non 109.4, ed. Boyer and McKeon, p. 356.
} 